\title{
Characterization of Laciana Valley District mine water as geothermal resource
}

\author{
Alejandro Matas ${ }^{1,2,}$, Francisco García-Carro ${ }^{2}$ and Jorge Loredo ${ }^{1}$ \\ ${ }^{1}$ Department of Mining Methods and Prospection, University of Oviedo, C/Independencia, 13, 33004 Oviedo, Asturias, Spain. \\ ${ }^{2} \mathrm{I}+\mathrm{D}+\mathrm{i}$ Department at Magna Dea, S.L. C/Posada Herrera 2,2 33002 Oviedo, Asturias, Spain.
}

\begin{abstract}
Laciana Valley District is a coal mining region located in northern Spain. This region counts with several mining facilities, among them: eight underground mines (six mountain mines and two mine shafts) and three open pit mines. Nowadays, all the mining facilities have been closed down and are flooded. The water found inside them could be used as a geothermal resource due to its thermal properties and the proximity to population. The aim of the study is to analyze the water of the facilities located in Laciana Valley and determine its potential to be used as a geothermal resource for a district heating system. In order to achieve this goal an extensive field work has been performed, nine different mine water discharges have been chosen and several water characteristics have been selected for analysis. The parameters measured have been $\mathrm{pH}$, conductivity, hardness, temperature, turbidity and alkalinity. The results have been evaluated in order to determine the fluctuations of the physico-chemical parameters throughout a hydrological year and the mining facilities have been compared between each other regarding their mine water quality. The analysis of all the information gathered in the study shows a noteworthy thermal potential in the water of the abandoned mines of the region.
\end{abstract}

\section{Introduction}

Flooded underground mines provide an outstanding opportunity to extract low-grade geothermal energy. In the last ten years numerous research and commercial initiatives have been undertaken in Europe to develop abandoned coal mining fields into low-temperature resources [1]. This paper is focused on Laciana Valley District's coal mine facilities, located in northern Spain. Nowadays, all the mining facilities have fallen into disuse and are flooded. Coal mining began in the beginning of the 20th century and continued as the primary industry of the town until 2008 when the global economic crisis took its toll. With the main industry removed, the region entered a period of economic and social readjustment and had to strive to develop new industries. The use of mine water as a renewable heating source could contribute to the sustainable regeneration of former mining areas, providing both jobs and secure, low carbon heating energy [2].

The application of mine water for heating and cooling applications has been well known for quite some time, but still not many installations have been documented at a world scale, as of 2013 only 20 were documented [3].

According to [4] there are some advantages of flooded mines as compared to natural aquifers:

- excellent heat exchange surface (area) from rock to water caused by mining,

- the geological situation is usually well known

*Corresponding author: jloredo@uniovi.es and documented,

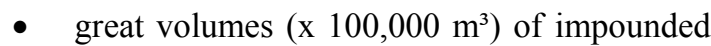
mine water (partly $>20^{\circ} \mathrm{C}$ ),

- high permeability and productive discharge of water (dekalitre/s),

- shafts and tunnels for the installation of pumps and heat pump systems exist and are accessible without bigger efforts,

- suitable locations for the installation of pumps and for re-infiltration of cooled water.

The first mayor abandoned coal mine water power station opened at Heerlen in the Netherlands in 2008. It currently uses $32{ }^{\circ} \mathrm{C}$ water extracted from underground coal workings through boreholes in the Dutch coal mining heartland. This scheme is now used to heat three hundred homes and businesses, with an estimated 55\% reduction in $\mathrm{CO} 2$ emission compared to conventional water heating systems [1].

Previously to the achievement of the Mine water Project in Europe there has been several mine water heat recovery projects carried out as stated by [3]. In the late 1980s the mine water of a flooded underground coal mine was used as a geothermal resource at Springill, Canada. Mine water at $18^{\circ} \mathrm{C}$ supplied to heat pumps used to heat and cool several buildings including manufacturing facilities and a restaurant [5]. In Germany there have been numerous underground mines whose water have been used to heat public buildings such as nursing homes, high schools or swimming pools [4]. These mines are 
located in the Rhenish Massif (Essen and Sachsen) where a total number of five projects have been implemented between the late 1980s and 2007. It has been estimated that $3000 \mathrm{MWt}$ heat energy is available in the waters of flooded coalfields of Europe [6]. Nevertheless, the use of mine water as a renewable heating source has been also appealing out of Europe, there are notorious facilities in USA and Canada such as a flooded lead mine in Park Hills, Missouri, where water is extracted from workings between 11 and $133 \mathrm{~m}$ below ground level and has been used to heat and cool a Municipal Building (area $753 \mathrm{~m} 2$ ) since 1995 [7].

More recently, there has been a powerful impetus in Asturias, Northern Spain, provided by the private company HUNOSA to focus on heat recovery in its mines. According to [8], mine water reservoirs in Central Asturias could reach a potential of 40 million $\mathrm{m} 3$ per year for water supply, and an energy supply capacity close to 260,000 thermal MWh per year. Mine water from a mining reservoir (Barredo-Figaredo) has been already used as geothermal resource to heat and cool some University buildings and there are ongoing projects to extend these applications to other potential future users in the area [9].

UK has been another major promoter of this kind of energy, the Scottish Parliament commissioned a report on the energy and environmental benefits of using waterwater heat pumps, with special reference to the waters of abandoned coal mines [8]. In Shettleston, Scotland mine water at $12^{\circ} \mathrm{C}$, from $100 \mathrm{~m}$ deep borehole drilled into flooded underground coal mine workings, is used for space heating and pre-heating of domestic hot water for 16 residential properties (1600 $\mathrm{m} 2$ total). In Lumphinnans, also Scotland, mine water at $15^{\circ} \mathrm{C}$ supplied to heat pumps of rated capacity $65 \mathrm{~kW}$, producing hot water at $55^{\circ} \mathrm{C}$. Used for space heating and pre-heating of domestic hot water for 16 residential properties (1600 $\mathrm{m} 2$ total) [7]. In South Wales region approximately three thousand litres of water are being drained or pumped from old mine workings per second. Using discharge and temperature data it is estimates that this is $72 \mathrm{MWof}$ potential heating energy [10].

These examples provide good proof of the potential of underground mine waters as a geothermal resource. The heat in mine water is a valuable resource that is currently being wasted when it is discharged to a receiving stream. Acid mine drainage (AMD) causes environmental pollution that affects many countries having historic or current mining industries [11]. The effective harnessing of energy from mine water, either from naturally overflowing mines or pumped shafts/boreholes, can turn an environmental liability (mine water) into an environmental asset (a clean energy source) [7]. The extraction of energy from them, which is immediately returned to the mine, produces no combustion gases and leaves no chemical residue on the surface. This energy source, when in routine use, produces no harm to the local environment [5].

\section{Area of study}

This study focusses on Laciana Valley District abandoned mines, located in Northern Spain, close to the city of Villablino (Fig. 1).

The geology of Laciana region consists of a thick (up to $3.000 \mathrm{~m}$ ) sedimentary sequence of Estephanian age. They crop out along a narrow band of $4 \mathrm{~km}$ wide and up to $25 \mathrm{~km}$ long. This unit is known as "The Villablino basin" and is supported by Precambrian and Palaeozoic materials. Main lithofacies include mudstones, siltstones, sandstones (litharenites), coal seams and minor quantities of limestones and conglomerates. Coal seams thickness varies from 0,40 to 2 meters, reaching 3 meters in extraordinary cases (Paulina mountain mine) [12].

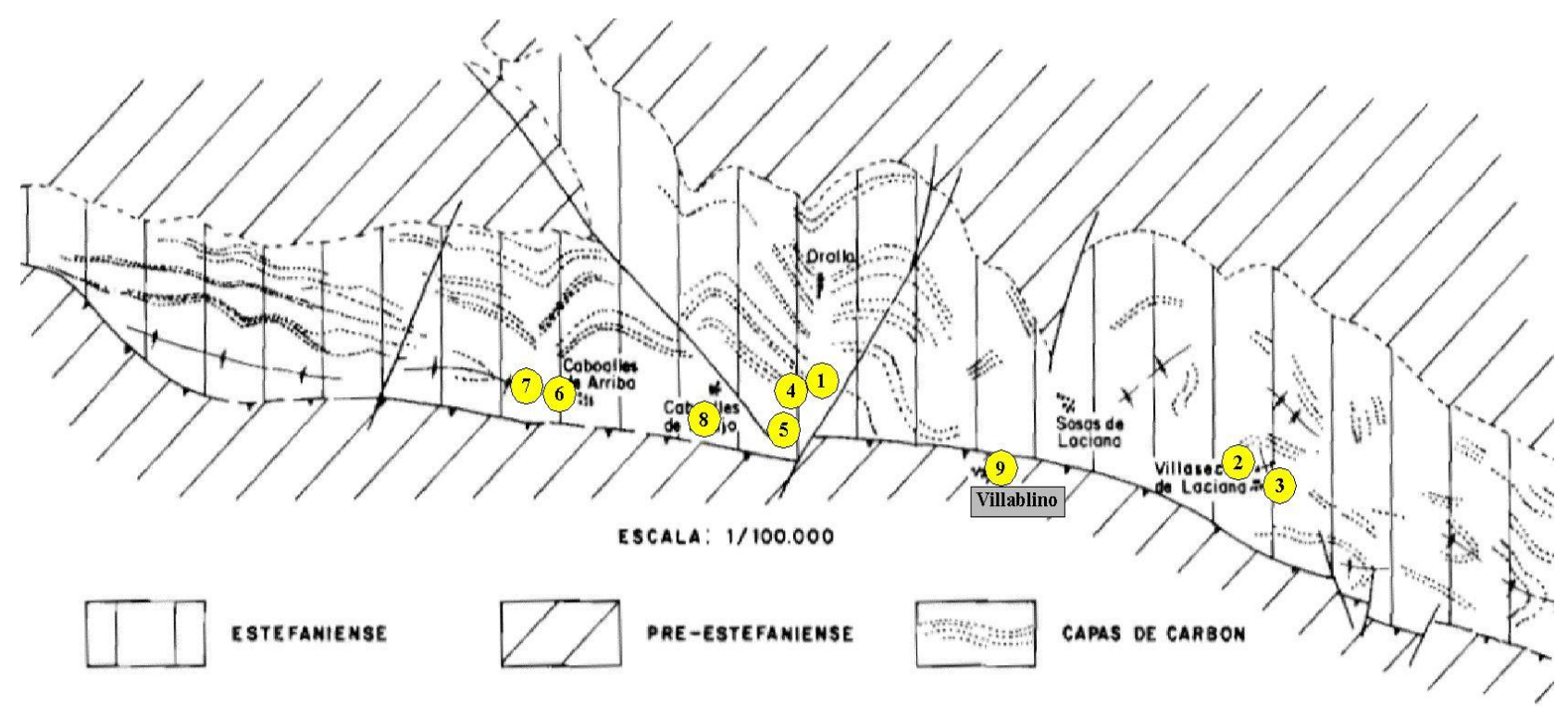

Figure 1. Geological scheme of Laciana mining area and sampling points location [12]. 
There are eleven different mining facilities (eight underground mines and three open pit mines). Nine naturally overflowing points have been selected to analyze the mine water characteristics in order to research their value as low enthalpy geothermal resource:

1. Calderón mountain mine

2. Lumajo mountain mine

3. Carrasconte mountain mine

4. Calderón transformers

5. Bolsada Caboalles de Abajo mountain mine

6. Bolsada Caboalles de Arriba mountain mine

7. Paulina mountain mine

8. María mine shaft

9. Transversal Villablino mountain mine

\section{Materials and methods}

Four sampling campaigns were performed, covering a full hydrological year (in April-July-November-January 2017-2018). Nine sampling points were identified and detailed in point 2 . All of the sample points were selected based on criteria such as accessibility, solicitation and location in the vicinity of population. Before a sample was collected, the bottle was rinsed three times with the water to be sampled. During the site inspection all sampling points were photographed and documented and field measurements of $\mathrm{pH}$, conductivity, hardness, temperature and turbidity were recorded. Temperature and $\mathrm{pH}$ were measured with a Hanna instrument (Waterproof $\mathrm{pH}$ meter HI9024C), turbidity was obtained with a Hanna's turbidity meter HI 93703, conductivity was collected with Hanna's conductivity meter HI9033, hardness was measured through a JBL total hardness test and alkalinity was obtained through a JBL alkalinity test. Equipment was calibrated before each day's fieldwork and all water samples were refrigerated as soon as possible after collection.

\section{Results and discussion}

\subsection{Physicochemical characteristics}

Table 1 shows temperature and geochemical data for all mine waters that were included in this analysis. The vast majority of mine water flows treated has circum-neutral $\mathrm{pH}$ (overall mean: 7.0; range: 6.36-7.55). Most of the sites display small temperature variations during the monitoring period; however variation between the study sites is bigger than $5{ }^{\circ} \mathrm{C}$. The lowest temperatures are recorded at Bolsada Caboalles de Arriba mountain mine $\left(9.8^{\circ} \mathrm{C}\right)$ while the warmest temperature $\left(15.5^{\circ} \mathrm{C}\right)$ was recorded at Calderón transformers. Warm water was also found in Calderón mountain mine $\left(15.2^{\circ} \mathrm{C}\right)$, María mine shaft $\left(14.1^{\circ} \mathrm{C}\right)$ and Transversal Villablino mountain mine $\left(14,7^{\circ} \mathrm{C}\right)$. Values of turbidity differ substantially from a study site to another. A high turbidity can be found in Carrasconte (83 NTU) mountain mine, whereas in Calderón mountain mine or Transversal Villablino mountain mine waters have low turbidity $(2,29$ and 2,11 respectively). The conductivity variation is reasonably stable throughout the year. The low values $(<2000$ $\mu \mathrm{S} / \mathrm{cm}$ ) of the most of the sampling sites are in line with the conductivity found in shallow fresh ground waters. Mine waters from greater depth tend to have higher conductivities due to longer rock-water interaction, greater potential influence of saline waters, and inflows of strata water with higher conductivity [13]. All the waters evaluated can be classified as very hard according with their hardness (400-1000 $\mu \mathrm{S} / \mathrm{cm})$. Lumajo mountain mine and Bolsada Caboalles de Arriba mountain mine are the samples sites with softest waters, nevertheless their hardness is over $250 \mathrm{mg} / \mathrm{l} \mathrm{CaCO} 3$. Most of the samples show alkalinities lower than those found in mine water discharges of northern Spain [14]. However, Carrasconte, Calderón transformers and María mine shaft alkalinity is higher than the others and similar to the ones found in Asturias [14].

\subsection{Laciana Valley District's mine water as a geothermal resource}

Compared to known systems using mine water as a heat source the conditions in the monitored mines in Laciana region seem to be positive. Watzlaf and Ackman [15] list several locations where mine water is used in geothermal systems at temperatures comparable or lower than those reported in the current paper. In Springhill, Nova Scotia, Canada, water is used at temperature of $18{ }^{\circ} \mathrm{C}$. In Park Hills, Missouri, United States, heat pumps works with mine water at $14^{\circ} \mathrm{C}$. In Shettleston, Scotland, United Kingdom, mine water at $12^{\circ} \mathrm{C}$ is used. In Lumphinnans, Scotland, United Kingdom, mine water used for heating has $14.5^{\circ} \mathrm{C}$. In Markham Colliery, Derbyshire, Alkane Energy is using geothermal heat from mine water at $15^{\circ} \mathrm{C}$ [16]. Economic assessments have been performed in several of the locations cited. For instance, the payback period in Park Hills was calculated to be about 4.6 years [15] and the payback period for the additional capital cost in Springhill was estimated to be less than one year [5].

In order to determine the scaling and corrosion potential of Laciana Valley District mine water in a heat pump system, the Langelier Saturation Index (LSI) and the Ryznar Stability Index (RSI) are going to be calculated. These indices are commonly used in the water treatment industry to evaluate the nature of a water source [17] and their interpretation is shown in table 2. Total dissolved solids (TDS), $\mathrm{pH}$, temperature, Calcium hardness and $\mathrm{M}$ alkalinity are necessary to calculate the Langelier Saturation Index. All the necessary parameters have been obtained from the analysis carried out but TDS which has been calculated using two different methods.

On one hand, TDS includes all solids that are dissolved in water, hence, its value is very similar to the sum of the quantities of the constituents of the water analyzed separately [18]. Hardness is represented mostly by $\mathrm{Ca} 2+$ and $\mathrm{Mg} 2+$, while alkalinity is represented mostly by HCO3- [17]. Therefore TDS must be at least as high as the addition of hardness and alkalinity in ppm or 
Table 1. Physicochemical data for the sampling points identified.

\begin{tabular}{|c|c|c|c|c|c|c|c|}
\hline Sample & pH & $\begin{array}{c}\text { Temperature } \\
\left({ }^{\circ} \mathrm{C}\right)\end{array}$ & $\begin{array}{c}\text { Turbidity } \\
\text { (NTU) }\end{array}$ & $\begin{array}{c}\text { Conductivity } \\
(\mu \mathrm{S} / \mathrm{cm})\end{array}$ & $\begin{array}{c}\text { Hardness } \\
\text { (mg/l CaCO3) }\end{array}$ & $\begin{array}{c}\text { Alkalinity } \\
\text { (ppm CaCO3) }\end{array}$ & $\begin{array}{c}\text { TDS (ppm } \\
\text { CaCO3) }\end{array}$ \\
\hline \multicolumn{8}{|c|}{ Calderón mountain mine } \\
\hline April 17 & 7,1 & 14,1 & 1,03 & 1343 & 836,6 & 327 & 1163,6 \\
\hline July 17 & 6,73 & 15,2 & 2,29 & 1602 & 836,6 & 305,2 & 1141,8 \\
\hline November 17 & 7,55 & 15,1 & 1,61 & 1281 & 729,8 & 327 & 1056,8 \\
\hline January 18 & 7,38 & 13,6 & 0,65 & 1349 & 890 & 370,6 & 1260,6 \\
\hline Mean & 7,19 & 14,50 & 1,40 & 1393,75 & 823,25 & 332,45 & 1155,7 \\
\hline \multicolumn{8}{|c|}{ Lumajo mountain mine } \\
\hline April 17 & 6,98 & 12,5 & 15,85 & 649 & 462,8 & 327 & 789,8 \\
\hline July 17 & 6,67 & 12,9 & 14,22 & 540 & 284,8 & 261,6 & 546,4 \\
\hline November 17 & 7,17 & 13,1 & 5 & 408 & 267 & 196,2 & 463,2 \\
\hline January 18 & 7,33 & 13,1 & 6,82 & 515 & 231,4 & 239,8 & 471,2 \\
\hline Mean & 7,04 & 12,90 & 10,47 & 528,00 & 311,50 & 256,15 & 567,65 \\
\hline \multicolumn{8}{|c|}{ Carrasconte mountain mine } \\
\hline April 17 & 6,45 & 12,5 & 83 & 1840 & 1121,4 & 610,4 & 1731,8 \\
\hline July 17 & 6,5 & 12,7 & 47,51 & 1767 & 854,4 & 545 & 1399,4 \\
\hline November 17 & 6,71 & 12,5 & 64 & 1358 & 1068 & 588,6 & 1656,6 \\
\hline January 18 & 6,71 & 12,3 & 13,4 & 1690 & 907,8 & 566,8 & 1474,6 \\
\hline Mean & 6,59 & 12,50 & 51,98 & 1663,75 & 987,90 & 577,70 & 1565,6 \\
\hline \multicolumn{8}{|c|}{ Calderón transformers } \\
\hline April 17 & 7,03 & 14,3 & 10,79 & 1541 & 854,4 & 457,8 & 1312,2 \\
\hline July 17 & 6,87 & 15,5 & 10,48 & 2340 & 996,8 & 501,4 & 1498,2 \\
\hline November 17 & 7,08 & 15,3 & 16,92 & 2070 & 1192,6 & 545 & 1737,6 \\
\hline January 18 & 7,17 & 13,5 & 5,57 & 1787 & 783,2 & 457,8 & 1241 \\
\hline Mean & 7,04 & 14,65 & 10,94 & 1934,50 & 956,75 & 490,50 & 1447,25 \\
\hline \multicolumn{8}{|c|}{ Bolsada Caboalles de Abajo mountain mine } \\
\hline April 17 & 6,81 & 12,3 & 6,92 & 923 & 534 & 305,2 & 839,2 \\
\hline July 17 & 6,65 & 12,4 & 5,83 & 1123 & 534 & 305,2 & 839,2 \\
\hline November 17 & 7,05 & 12,3 & 2,16 & 828 & 605,2 & 261,6 & 866,8 \\
\hline January 18 & 6,86 & 11,9 & 8,46 & 1306 & 676,4 & 327 & 1003,4 \\
\hline Mean & 6,84 & 12,23 & 5,84 & 1045,00 & 587,40 & 299,75 & 887,15 \\
\hline \multicolumn{8}{|c|}{ Bolsada Caboalles de Arriba mountain mine } \\
\hline April 17 & 7,13 & 9,8 & 0,48 & 233 & 249,2 & 130,8 & 380 \\
\hline July 17 & 6,85 & 9,8 & 30,53 & 397 & 231,4 & 87,2 & 318,6 \\
\hline November 17 & 7,23 & 10 & 2,33 & 312 & 267 & 130,8 & 397,8 \\
\hline January 18 & 7 & 10,2 & 7,48 & 182 & 106,8 & 65,4 & 172,2 \\
\hline Mean & 7,05 & 9,95 & 10,21 & 281,00 & 213,60 & 103,55 & 317,15 \\
\hline \multicolumn{8}{|c|}{ Paulina mountain mine } \\
\hline April 17 & 6,59 & 10,6 & 19,17 & 527 & 302,6 & 261,6 & 564,2 \\
\hline July 17 & 6,36 & 10,3 & 6,21 & 458 & 231,4 & 152,6 & 384 \\
\hline November 17 & 6,61 & 9,6 & 0,5 & 365 & 320,4 & 196,2 & 516,6 \\
\hline January 18 & 6,86 & 8,7 & 21,73 & 247 & 142,4 & 130,8 & 273,2 \\
\hline Mean & 6,61 & 9,80 & 11,90 & 399,25 & 249,20 & 185,30 & 434,5 \\
\hline \multicolumn{8}{|c|}{ María mine shaft } \\
\hline April 17 & 6,9 & 14 & 8,89 & 806 & 427,2 & 457,8 & 885 \\
\hline
\end{tabular}




\begin{tabular}{cccccccc} 
July 17 & 6,61 & 14,1 & 12,68 & 1000 & 480,6 & 436 & 916,6 \\
November 17 & 6,81 & 13,7 & 12,01 & 762 & 462,8 & 501,4 & 964,2 \\
January 18 & 6,89 & 13,7 & 8,69 & 992 & 462,8 & 523,2 & 986 \\
Mean & 6,80 & 13,88 & 10,57 & 890,00 & 458,35 & 479,60 & 937,95 \\
& & \multicolumn{7}{c}{ Transversal } & Villablino mountain mine \\
April 17 & 6,71 & 14,5 & 2,11 & 765 & 373,8 & 305,2 & 679 \\
July 17 & 6,5 & 14,6 & 1,32 & 878 & 391,6 & 348,8 & 740,4 \\
November 17 & 7,29 & 14,7 & 0,14 & 703 & 445 & 370,6 & 815,6 \\
January 18 & 7,3 & 14,7 & 0,05 & 845 & 409,4 & 348,8 & 758,2 \\
Mean & 6,95 & 14,63 & 0,91 & 797,75 & 404,95 & 343,35 & 748,3 \\
\hline
\end{tabular}

milligram per liter. On the other hand there is a relation between TDS expressed in milligram per liter and electrical conductivity in microsiemens per centimeter at $25^{\circ} \mathrm{C}$. The correlation factor varies between 0.55 and 0.80 and is higher with bigger values of TDS and conductivity [19]. An estimation with the factor 0.64 has been made, as proposed by [20].

LSI and RZI have been calculated resulting very similar for both approximations of the TDS. The results displayed in tables 1 and 3 consider TDS as the addition of alkalinity and hardness.

As shown in table 3, LSI of Laciana Valley District mine waters is mostly slightly corrosive or balanced. Nevertheless some locations such as Bolsada Caboalles de Arriba y Paulina mountain mine have nearly serious corrosive waters and Calderón mountain mine and Calderón transformers have balance or slightly scaling waters

\section{Conclusion}

Laciana Valley District is a mining region, located in northern Spain, which counts with several abandoned mining facilities. The mine water of nine different effluent points has been analyzed in this paper. Very stable mine water temperatures throughout the year and relatively high value of water temperature at the surface discharge points show that these waters have great potential for geothermal energy generation. Several geothermal systems from around the globe exploit mine water at temperatures comparable or lower than those reported in this paper. The different parameters analyzed (temperature, $\mathrm{pH}$, conductivity, hardness, turbidity and alkalinity) show relatively low variations during the year but present important fluctuations from one sample site to another. Calderón mountain mine and Calderón transformers have been proved to be the best options for heat recovery system installations, followed by Transversal Villablino mountain mine and María mine shaft. The relative stability of the studied parameters suggests that these waters represent a dependable thermal resource that, given current levels of demand, can be sustainably exploited for long-term geothermal use. However, it must be cautioned that some of these waters can cause corrosion problems in pipes and heat exchangers and some actions to prevent them should be applied. The results of this study are a sound base for further evaluation of Laciana Valley District mine water as geothermal resource. The evaluation of profitable water treatments and an economic assessment of the facilities might be fruitful topics to develop.

Table 2. Interpretation of the Langelier Saturation Index and Ryznar Stability Index [21].

\begin{tabular}{cccc}
\hline LSI Index Value & Indication & RSI Index Value & Indication \\
\hline 2,00 & Scale forming but non corrosive & $4.00-5.00$ & Heavy scale \\
0,50 & Slightly scale forming and corrosive & $5.00-6.00$ & Light scale \\
0,02 & Balanced but pitting corrosion possible & $6.00-7.00$ & Little scale or corrosion \\
$-0,5$ & Slightly corrosive but non-scale forming & $7.00-7.50$ & Corrosion significant \\
$-2,00$ & Serious corrosion & $7.50-9.00$ & Heavy corrosion \\
& & $>9.00$ & Corrosion intolerable \\
\hline
\end{tabular}

Table 3. LSI and RSI of Laciana region mine water.

\begin{tabular}{|c|c|c|c|c|}
\hline Sample & $\begin{array}{c}\text { Langelier } \\
\text { Saturation Index } \\
\text { (LSI) }\end{array}$ & & $\begin{array}{l}\text { Ryznar Stability } \\
\text { Index (RSI) }\end{array}$ & \\
\hline $\begin{array}{c}\text { Calderón mountain } \\
\text { mine }\end{array}$ & 0,43 & $\begin{array}{l}\text { (Slightly scale forming } \\
\text { and corrosive) }\end{array}$ & 6,33 & $\begin{array}{l}\text { (Little scale or } \\
\text { corrosion) }\end{array}$ \\
\hline $\begin{array}{l}\text { Lumajo mountain } \\
\text { mine }\end{array}$ & $-0,26$ & $\begin{array}{l}\text { (Balanced but pitting } \\
\text { corrosion possible) }\end{array}$ & 7,56 & (Heavy corrosion) \\
\hline
\end{tabular}




\begin{tabular}{|c|c|c|c|c|}
\hline $\begin{array}{l}\text { Carrasconte mountain } \\
\text { mine }\end{array}$ & 0,10 & $\begin{array}{l}\text { (Slightly scale forming } \\
\text { and corrosive) }\end{array}$ & 6,40 & $\begin{array}{l}\text { (Little scale or } \\
\text { corrosion) }\end{array}$ \\
\hline Calderón transformers & 0,50 & $\begin{array}{l}\text { (Scale forming but non } \\
\text { corrosive) }\end{array}$ & 6,03 & $\begin{array}{l}\text { (Little scale or } \\
\text { corrosion) }\end{array}$ \\
\hline $\begin{array}{l}\text { Bolsada Caboalles de } \\
\text { Abajo mountain mine }\end{array}$ & $-0,14$ & $\begin{array}{l}\text { (Balanced but pitting } \\
\text { corrosion possible) }\end{array}$ & 7,13 & $\begin{array}{l}\text { (Corrosion } \\
\text { significant) }\end{array}$ \\
\hline $\begin{array}{l}\text { Bolsada Caboalles de } \\
\text { Arriba mountain mine }\end{array}$ & $-0,84$ & $\begin{array}{l}\text { (Slightly corrosive but } \\
\text { non-scaleforming) }\end{array}$ & 8,73 & (Heavy corrosion) \\
\hline Paulina mountain mine & $-0,98$ & $\begin{array}{l}\text { (Slightly corrosive but } \\
\text { non-scaleforming) }\end{array}$ & 8,57 & (Heavy corrosion) \\
\hline María mine shaft & $-0,06$ & $\begin{array}{l}\text { (Balanced but pitting } \\
\text { corrosion possible) }\end{array}$ & 6,92 & $\begin{array}{l}\text { (Little scale or } \\
\text { corrosion) }\end{array}$ \\
\hline $\begin{array}{l}\text { Transversal Villablino } \\
\text { mountain mine }\end{array}$ & $-0,08$ & $\begin{array}{l}\text { (Balanced but pitting } \\
\text { corrosion possible) }\end{array}$ & 7,12 & $\begin{array}{l}\text { (Corrosion } \\
\text { significant) }\end{array}$ \\
\hline
\end{tabular}

\section{References}

1. R. Verhoeven, E. Willems, V. Harcouët-Menou, E. De Boever, L. Hiddes, P.O. t. Veld, E. Demollin, Energy Procedia 46 58-67 (2014).

2. G. Farr, S. Sadasivam, Manju, I.A. Watson, H.R. Thomas, D. Tucker, Int. J. Coal Geol. 164 92-103 (2016).

3. M. Preene, P.L. Younger, Min. Technol. 123 107118 (2014).

4. G. Wieber, S. Pohl, Int. Mine Water Assoc. Congr. 113-116 (2008).

5. A. Jessop, Proceedings 17 463-468 (1995).

6. R. Díez, M. Díaz-Aguado, Energies 7 4241-4260 (2014).

7. D. Banks, H. Skarphagen, R. Wiltshire, C. Jessop, Geol. Soc. London, Spec. Publ. 236 499-513 (2004).

8. S. Jardón, A. Ordóñez, R. Álvarez, P. Cienfuegos, J. Loredo, Mine Water Environ. 32 139-151 (2013).

9. J. Loredo, A. Ordóñez, S. Jardón, R. Álvarez, Imwa 2011 177-182 (2011).

10. D.J. Thomas, Fuel 189445 (2017).

11. D.B. Johnson, K.B. Hallberg, Sci. Total Environ. 338 3-14 (2005).
12. IGME, Mapa Geológico de España E. 1:50.000 Villablino, Spain, 1982.

13. M.T. Bailey, C.J. Gandy, I.A. Watson, L.M. Wyatt, A.P. Jarvis, Int. J. Coal Geol. 164 77-84 (2016).

14. C. Loredo, A. Ordóñez, E. Garcia-Ordiales, R. Álvarez, N. Roqueñi, P. Cienfuegos, A. Peña, N.M. Burnside, Sci. Total Environ. 576 59-69 (2017).

15. G. Watzlaf, T. Ackman, Mine Water Environ. 25 114 (2006).

16. A.P. Athresh, A. Al-Habaibeh, K. Parker, Int. J. Coal Geol. 164 69-76 (2016).

17. K. Rafferty, Geo-Heat Center, Klamath Falls, OR 11-16 (2000).

18. C.S. Howard, Ind. Eng. Chem. Anal. Ed. 5 4-6 (1933).

19. E.A. Atekwana, E.A. Atekwana, R.S. Rowe, D.D. Werkema, F.D. Legall, J. Appl. Geophys. 56 281294 (2004).

20. J.U. Iyasele, D.J. Idiata, D. J, Int. J. Eng. Res. Rev. 3 40-48 (2015).

21. Carrier, Handbook of Air Conditioning System Design (1965) 